\title{
ESTIMATION OF ALUMINIUM POLLUTION IN OAK STANDS ON THE KROTOSZYN PLATEAU
}

\author{
JADWIGA OPYDO \\ Institute of Chemistry, Poznań University of Technology \\ 60-965 Poznań, Poland
}

(Received: May 6, 1995. Accepted: May 30, 1996)

\begin{abstract}
Estimation of the degree of aluminium absorption by oak stands on the Krotoszyn Plateau and on reference areas is reported in this paper. Soil $\mathrm{pH}$, the content of exchangeable aluminium in soil and the content of aluminium in the xylem and roots of Quercus robur $\mathrm{L}$ were determined. The performed studies show a very strong acidification of soils from the investigated areas of the Krotoszyn Plateau; pH vs. $1 \mathrm{M} \mathrm{KCl}$ did not exceed 4.0, whereas the content of exchangeable $\mathrm{Al}$ in some places was $>50 \mathrm{mg} / 100 \mathrm{~g}$. The results also showed an elevated content of aluminium in the wood and roots of oaks growing on the Krotoszyn Plateau as compared to oaks in Zawiercie (near a Steel Mill), where the reaction of soil is neutral. The content of $\mathrm{Al}$ in the xylem of oaks from the Krotoszyn Plateau was over the range 3.8-9.9 $\mu \mathrm{g} / \mathrm{g}$, in the roots 198-499 $\mu \mathrm{g} / \mathrm{g}$, that in the xylem and roots of oaks in Zawiercie was $1.5 \mu \mathrm{g} / \mathrm{g}$ and $56 \mu \mathrm{g} / \mathrm{g}$, respectively.
\end{abstract}

KEY WORDS: Quercus robur, Krotoszyn Plateau, pH, aluminium.

\section{INTRODUCTION}

Oak stands on the Krotoszyn Plateau (West-Central part of Poland) are suffering from the collapse of their health condition, leading to decline. This process, however, was conducive to developing intense studies and observations aimed at finding the reason of oak decline (Siwecki 1987, 1989, Siwecki and Ratajczak 1991, Ważny 1991, Woźny and Siwecki 1991). This problem, however, has not been clearly explained.

The present paper is a part of a wide research program, the objective of which is to evaluate the influence of industrial pollutions on the decline of oak stands on the Krotoszyn Plateau. In the earlier paper (Opydo 1994) the degree of oak stand pollution (soil and wood) with heavy metals - zinc, cadmium, lead and copper was determined. The present work deals with an increasing process of soil degradation as a result of its gradual acidification. A decreasing $\mathrm{pH}$ of soil is favourable to the release of aluminium $\mathrm{Al}^{3+}$ ions from the crystal soil mineral net, which constitute an essential component of the soil sorption complex when they appear in the soil solution. This is the so-called exchangeable aluminium, which may induce a number of unfavourable phenomena affecting plant development and growth chiefly through the root system (Kabata-Pendias and Pendias 1979, Stienen and Bauch 1988, Sharpe et al. 1993). In this connection $\mathrm{pH}$ of soils was measured, the content of exchangeable aluminium in soils and the aluminium content in the wood and roots of oaks were determined. The studies covered oak stands on four investigated areas established by the Institute of Dendrology in Kórnik, Polish Academy of Sciences. In view of a small number of reference monographs the studies also covered stands in the copper region (near the Głogów Smelter), in Zawiercie (near a Steel Mill) and in Kórnik (Experimental Forest Zwierzyniec).

\section{MATERIALS AND METHODS}

Characteristics of the oak stands under study are presented in Table 1. All the stands contained the same oak species Quercus robur $\mathrm{L}$.

Soil samples were taken at three depths: $0-20 \mathrm{~cm}, 20-40 \mathrm{~cm}$ and $40-60 \mathrm{~cm}$. The reaction of soil was evaluated by the potentiometric method. Soil $\mathrm{pH}$ was measured in the soil+water (1:2.5) suspension and in the soil+1 $\mathrm{M} \mathrm{KCl}(1: 2.5)$ suspension. The content of exchangeable aluminium was determined by the method of Sokołov. This method consists in determination of aluminium content from the difference between exchangeable acidification estimated in $1 \mathrm{M} \mathrm{KCl}$ and the remaining acidification after removal of $\mathrm{Al}^{3+}$ by $\mathrm{NaF}$.

Wood samples were taken from several oak trees on each investigated forest area with a Pressler's bore at height of $1.30 \mathrm{~m}$ from the ground. Roots samples were also taken from several trees on each investigated area - from the main and lateral roots. They were dried up $\left(105^{\circ} \mathrm{C}, 24 \mathrm{~h}\right)$, and then, disintegrated. Wood and roots mineralization was done in a mixture of $30 \% \mathrm{H}_{2} \mathrm{O}_{2}+$ conc. $\mathrm{HNO}_{3}$. Aluminium concentrations were measured by adsorptive stripping voltammetry, using a hanging mercury drop electrode. For aluminium complexation, solochrome violet $\mathrm{SR}$ was used in the case of $\mathrm{Al}$ determination in the xylem of trees and alizarin S in the case of $\mathrm{Al}$ determination in roots (Opydo 1995). 
TABLE 1. Condition of the oak stands under study.

\begin{tabular}{llrl}
\hline Location & Research area & Age of trees & \multicolumn{1}{c}{$\begin{array}{l}\text { Classes of } \\
\text { damaged trees }\end{array}$} \\
\hline Krotoszyn Plateau & Jasne Pole 1 & 136 & 3 and 4 \\
& Jasne Pole 2 & 106 & 0 and 1 \\
& Jasne Pole 3 & 104 & 2 and 4 \\
& Potarzyca & 106 & 0 and 3 \\
\hline Copper basin & Biechów & about 80 & 0 and 2 \\
\hline Krakowsko-Częstochowska & Bogomice & about 80 & 0 \\
Upland & Zawiercie & about 130 & \\
\hline Kórnik & Experimental Forest & about 100 & \\
& Zwierzyniec & & 0 \\
\hline
\end{tabular}

x 0 - healthy trees; 1 - slightly damaged trees; 2 -medium damaged trees; 3 - strongly damaged trees; 4 - dead trees.

\section{RESULTS AND DISCUSSION}

Results of soil analysis are presented in Table 2. The performed studies show a very significant decrease in $\mathrm{pH}$ of soils from the areas of the Krotoszyn Plateau, copper region and Kórnik. In these cases, soil pH vs. $\mathrm{H}_{2} \mathrm{O}$ below 4.5 and soil $\mathrm{pH}$ vs. $\mathrm{KCl}<4$. This qualifies the studied soils as very acid.

The largest decrease in soil $\mathrm{pH}$ may be observed on the investigated areas Jasne Pole 1, 2 and in Potarzyca. Such a strong soil acidification entails the release of significant amounts of aluminium $\mathrm{Al}^{3+}$ ions from the soil.

The content of aluminium in the wood of oak trees is presented in Table 3. An elevated content of aluminium can be observed in the wood of oak trees from the areas characterizing by a hight content of exchangeable $\mathrm{Al}$ in comparison to oak trees from Zawiercie, where this phenomenon does not occur.

The largest concentrations of $\mathrm{Al}$ were found in the xylem of oak trees from the investigated areas of Jasne Pole 2 $(9.9 \mu \mathrm{g} / \mathrm{g})$, Potarzyca $(8.7 \mu \mathrm{g} / \mathrm{g})$ and Jasne Pole $1(5.4 \mu \mathrm{g} / \mathrm{g})$. Just on these areas the content of exchangeable aluminium in the soil was the highest amounting $53.8,42.8$ and $54.0 \mathrm{mg} / 100 \mathrm{~g}$, respectively.

Aluminium absorption by oak trees is more visible, when results concerning roots are compared (Table 3 ). The content of $\mathrm{Al}$ in the roots of oak trees from Zawiercie $(56 \mathrm{~g} / \mathrm{g})$ is con-

TABLE 2. Soil reaction and mobile aluminium content. Results of soil analysis from the Krotoszyn Plateau and comparative areas.

\begin{tabular}{lcccc}
\hline Research area & Soil layer cm & pH vs. $\mathrm{H}_{2} \mathrm{O}$ & $\mathrm{pH}$ vs. KCl & Mobile Al mg/100g \\
\hline Jasne Pole 1 & $0-20$ & 3.8 & 3.0 & 20.3 \\
& $20-40$ & 4.3 & 3.8 & 36.5 \\
Jasne Pole 2 & $40-60$ & 4.5 & 3.3 & 54.0 \\
& $0-20$ & 3.9 & 3.4 & 33.8 \\
Jasne Pole 3 & $20-40$ & 4.5 & 3.8 & 20.4 \\
& $40-60$ & 4.8 & 3.8 & 6.5 \\
Potarzyca & $0-20$ & 4.9 & 4.0 & 7.0 \\
& $20-40$ & 4.8 & 4.0 & 10.1 \\
Biechów & $40-60$ & 4.9 & 3.6 & 42.8 \\
& $0-20$ & 4.4 & 3.4 & 22.3 \\
Bogomice & $20-40$ & 4.6 & 3.4 & 4.5 \\
& $40-60$ & 5.0 & 3.4 & 5.3 \\
Zawiercie & $0-20$ & 4.9 & 4.0 & 0.1 \\
& $20-40$ & 4.9 & 3.8 & 9.9 \\
Kórnik & $40-60$ & 5.7 & 4.9 & 14.0 \\
& $0-20$ & 3.7 & 3.4 & 4.4 \\
& $20-40$ & 3.9 & 3.6 & - \\
& $40-60$ & 4.0 & 4.0 & - \\
\end{tabular}


TABLE 3. Concentration of aluminium in the wood and roots of oak $(\mu \mathrm{g} / \mathrm{g})$.

\begin{tabular}{lcc}
\hline Sampling location & \multicolumn{2}{c}{ Al content in } \\
\cline { 2 - 3 } & wood & $499 \pm 34$ \\
\hline Jasne Pole 1 & $5.4 \pm 0.3$ & $139 \pm 12$ \\
Jasne Pole 2 & $9.9 \pm 0.7$ & $279 \pm 17$ \\
Jasne Pole 3 & $3.8 \pm 0.1$ & $193 \pm 7$ \\
Potarzyca & $8.7 \pm 0.3$ & \\
Biechów & $3.3 \pm 0.2$ & $56 \pm 2$ \\
Bogomice & $3.8 \pm 0.2$ & \\
Zawiercie & $1.5 \pm 0.1$ & \\
Kórnik & $3.8 \pm 0.2$ & \\
\hline
\end{tabular}

Confidence intervals of means at a $95 \%$ confidence level, $\mathrm{n}=8$.

siderably lower than that in the roots of trees from the Krotoszyn Plateau $(192-499 \mu \mathrm{g} / \mathrm{g})$. However, in all the cases the content of $\mathrm{Al}$ in xylem and roots does not seem to be high. Though the literature has no communications on $\mathrm{Al}$ content in the xylem of oak trees, 6.1-23.8 $\mu \mathrm{g} / \mathrm{g} \mathrm{Al}$ (Matusiewicz and Barnes 1985) and 3.2-8.3 $\mu \mathrm{g} / \mathrm{g} \mathrm{Al}$ (Berneike et al. 1987) were found in spruce xylem. Fine roots of spruce were found to have $2800-4400 \mu \mathrm{g} / \mathrm{g} \mathrm{Al}$ (Berneike et al. 1987) and roots of red oak - 2300-3130 $\mu \mathrm{g} / \mathrm{g} \mathrm{Al}$ (Sharpe at al. 1993). On the other hand, $\mathrm{Al}$ concentration in soil extracts above $5 \mu \mathrm{g} / \mathrm{g}$ appears to be toxic to many plants (Kabata-Pendias and Pendias 1979). Therefore, concentrations of exchangeable aluminium found in soil and exceeding $50 \mathrm{mg} / 100 \mathrm{~g}(500 \mu \mathrm{g} / \mathrm{g})$ in some places, should not be neutral to trees. Perhaps low $\mathrm{pH}$ and a high content of mobile aluminium affect an increased uptake of copper through oaks on the areas of the Krotoszyn Plateau. In the work by Opydo (1994) an elevated content of copper was found in the wood of oaks from the areas of Krotoszyn Plateau as compared to the reference areas (copper content in oaks from Kórnik constitutes $0.6 \mu \mathrm{g} / \mathrm{g}, 1.1 \mu \mathrm{g} / \mathrm{g}$ from Zawiercie, 3.9-15.8 $\mu \mathrm{g} / \mathrm{g}$ from the copper region and 7.0-26.5 $\mu \mathrm{g} / \mathrm{g}$ from the Krotoszyn Plateau). It is know, that the degree of copper assimilation by plants is affected by such factors as temperature, reaction of the environment, $\mathrm{Al}, \mathrm{Ca}, \mathrm{Fe}, \mathrm{Zn}, \mathrm{P}$ and $\mathrm{N}$ contents in soil (Kabata-Pendias and Pendias 1979).

On the basis of the obtained results it may be inferred that copper absorbed by oaks and low $\mathrm{pH}$ of soils as well as considerable amounts of exchangeable aluminium in soil constitute factors, which may weaken trees making them more susceptible to pathogenic fungi and to attacks of harmful insects. These assumptions are supported by a good condition of oak stands growing on the ecologically threatened area near the Steel Mill in Zawiercie. This area, however, due to its location on the limestone rock - Krakowsko-Częstochowska Upland is characterized by neutral and alkaline soils.

\section{ACKNOWLEDGEMENTS}

This work was supported by the Polish Committee for Scientific Research (KBN), Grant No. 604119101.

The author wishes to express her sincere thanks to Professor R. Siwecki (Institute of Dendrology, Kórnik) for making possible wood, roots and soil sampling and to Mr. W. Zembrzuski for performing wood mineralization.

\section{LITERATURE CITED}

BERNEIKE W., EHLERS W., KNOTH J., RADEMACHER P., 1987. Element patterns in healthy and diseased norway spruce (Ficea abies) measured by inductively coupled plasma/atomic emission spectrometry and total reflection X-ray fluorescence spectrometry. Anal. Chim. Acta, 195: 289-297.

KABATA-PENDIAS A., PENDIAS H., 1979. Pierwiastki śladowe w środowisku biologicznym. Wydawn. Geolog., Warszawa.

MATUSIEWICZ H., BARNES R.M., 1985. Tree ring wood analysis after hydrogen peroxide pressure decomposition with inductively coupled plasma atomic emission spectrometry and electrothermal vaporization. Anal. Chem., 57: 406-411.

OPYDO J., 1994. Estimation of oak stand pollution with heavy metals on the Krotoszyn Plateau. Acta Soc. Bot. Pol., 63: 83-86.

OPYDO J., 1995. Determination of aluminium in sample trees by cathodic adsorptive stripping voltammetry. To be published

SHARPE W.E., SWISTOCK B.R., DEWALLE D.R., 1993. A greenhouse study of northern red oak seedling growth on two forest soils at different stages of acidification. Water, Air and Soil Pollut. 66: 122-133.

SIWECKI R., (ed), 1987. Ocena występowania, metody zapobiegania i zwalczania zjawiska zamierania drzewostanów dębowych Płyty Krotoszyńskiej. Ekspertyza zespołowa. Instytut Dendrologii PAN Kórnik.

SIWECKI R., 1989. A decline of oak forests caused by abiotic and biotic factors and attempts at biological research on this syndrome. Arb. Kórn. 34: 161-170.

SIWECKI R., RATAJCZAK M., 1991. Measurement of sanitary and healthy state of oak stands using conditiometer AS-1. In: Oak decline in Europe. Siwecki R., Liese W. (eds). Proc. Intern. Symposium, Kórnik, Poland, May 15-18, 1990, PWRiL-Oddz. w Poznaniu, pp. 221-225.

STIENEN H., BAUCH J., 1988. Element content in tissues of spruce seedlings from hydroponic cultures simulating acidification and deacidification. Plant and Soil 106: 231-238.

WAŻNY T., SIWECKI R., LIESE W., 1991. Dendroecological investigations on the oak decline on the Krotoszyn Plateau, Poland. In: Oak decline in Europe. Siwecki R., Liese W. (eds). Proc. Intern. Symposium, Kórnik, Poland, May 15-18, 1990, PWRiL-Oddz. w Poznaniu, pp. 233-239.

WOŹNY A., SIWECKI R., 1991. Ultrastructural studies of oak disease. In: Oak decline in Europe. Siwecki R., Liese W. (eds). Proc. Intern. Symposium, Kórnik, Poland, May 15-18, 1990, PWRiL-Oddz. w Poznaniu, pp. 315-319. 


\section{OCENA STOPNIA ZANIECZYSZCZENIA GLINEM \\ DRZEWOSTANÓW DĘBOWYCH PŁYTY KROTOSZYŃSKIEJ}

\section{STRESZCZENIE}

W pracy oceniono stopień absorpcji glinu przez drzewostany dębowe zlokalizowane na Płycie Krotoszyńskiej oraz na powierzchniach referencyjnych. Oznaczono: $\mathrm{pH}$ gleby, zawartość glinu wymiennego w glebie oraz zawartość glinu w ksylemie i w korzeniach dębów Quercus robur L. Przeprowadzone badania wykazują bardzo silne zakwaszenie gleb z powierzchni badawczych Płyty Krotoszyńskiej; pH wzgl. $1 \mathrm{M} \mathrm{KCl}$ nie przekracza 4,0, natomiast zawartość Al wymiennego miejscami > $50 \mathrm{mg} / 100 \mathrm{~g}$. Stwierdzono również podwyższenie zawartości Al w drewnie i w korzeniach dębów rosnących na Płycie Krotoszyńskiej, w porównaniu z drzewostanami zlokalizowanymi w Zawierciu, gdzie odczyn gleby jest obojętny. Zawartość Al w ksylemie dębów z Płyty Krotoszyńskiej mieści się w zakresie 3,8-9,9 $\mu \mathrm{g} / \mathrm{g}$ a w korzeniach w zakresie 198$499 \mu \mathrm{g} / \mathrm{g}$, natomiast zawartość Al w ksylemie dębów z Zawiercia wynosi 1,5 $\mu \mathrm{g} / \mathrm{g}$ a w korzeniach $56 \mu \mathrm{g} / \mathrm{g}$.

SŁOWA KLUCZOWE: Quercus robur, Płyta Krotoszyńska, pH gleby, aluminium. 